\title{
Is only severe vascular tortuosity a contraindication for the transfemoral approach of transcatheter aortic valve implantation?
}

Czy tylko bardzo kręty przebieg naczyń jest przeciwwskazaniem do przezcewnikowej przezudowej implantacji zastawki aortalnej?

\author{
Ahmet Çağrı Aykan, Tayyar Gökdeniz, Mustafa Tarık Ağaç, Şükrü Çelik \\ Department of Cardiology, Ahi Evren Chest and Cardiovascular Surgery Education and Research Hospital, Trabzon, Turkey
}

Postep Kardiol Inter 2012; 8, 3 (29): 265-268

DOI: $10.5114 /$ pwki.2012.30410

\begin{abstract}
Transcatheter aortic valve implantation is an alternative therapy for surgery in patients with aortic stenosis having high risk for surgery. Transcatheter aortic valve implantation may be performed through transfemoral, transaortic and transapical approaches. General anesthesia is generally required for transapical and transaortic approaches while epidural anesthesia is enough for the transfemoral approach. Although transfemoral access is suitable for most cases, patients having severe vascular tortuosity are candidates for the transapical approach. However, the approach for patients having vascular tortuosity along with poor respiratory capacity contraindicated for general anesthesia is controversial. Vascular complications that significantly increase patient morbidity and mortality are common in transfemoral transcatheter aortic valve implantation and generally associated with severe ilio-femoral tortuosities, severe calcification, porcelain aorta, and significant atheroma of the femoral and iliac vessels. But the effect of tortuosity alone was not evaluated well and complications were generally associated with vascular calcification. Stiff wires were commonly used in endovascular procedures. The vascular tortuosity can be straightened with stiff wires but the accordion effect, pseudo obstruction and vascular injury may also be observed. Herein we present a case of severe aortic stenosis successfully treated with transfemoral aortic valve implantation despite severe femoral, iliac and aortic tortuosity having severe chronic obstructive pulmonary disease.
\end{abstract}

Key words: transcatheter aortic valve implantation, tortuosity, transfemoral, aorta, stenosis.

\section{Streszczenie}

Przezcewnikowe wszczepienie zastawki aortalnej stanowi alternatywę dla operacji kardiochirurgicznej u chorych ze zwężeniem zastawki aortalnej i wysokim ryzykiem okołooperacyjnym. Przezcewnikowa implantacja zastawki aortalnej może zostać przeprowadzona drogą przezudową, przezaortalną i przezkoniuszkową. Przy wszczepieniu przezkoniuszkowym i przezaortalnym wymagane jest najczęściej znieczulenie ogólne, podczas gdy do wszczepienia przezudowego wystarcza znieczulenie zewnątrzoponowe. Chociaż dostęp przezudowy jest możliwy u większości pacjentów, chorzy z bardzo krętymi naczyniami są kandydatami do wszczepienia przezkoniuszkowego. Problematyczna pozostaje kwestia dostępu u pacjentów z bardzo krętymi naczyniami i niską pojemnością oddechową, co stanowi przeciwwskazanie do znieczulenia ogólnego. Powikłania naczyniowe, które znacznie zwiększają chorobowość i śmiertelność pacjentów, często towarzyszą przezcewnikowej przezudowej implantacji zastawki aortalnej i wynikają głównie z bardzo krętego przebiegu tętnic w odcinku biodrowo-udowym, masywnych zwapnień, obecności „porcelanowej” aorty i zaawansowanej miażdżycy tętnic udowych i biodrowych. Nie oceniano jednak wpływu krętego przebiegu naczyń, a powikłania wiązano głównie z obecnością zwapnień. Do zabiegów wewnątrznaczyniowych najczęściej stosuje się sztywne prowadniki. Kręty odcinek tętnicy można wyprostować za pomocą sztywnego prowadnika, ale może także dojść do wystąpienia objawu akordeonowego, pseudoniedrożności oraz uszkodzenia naczynia. Poniżej przedstawiono opis przypadku ciasnego zwężenia zastawki aortalnej leczonego skutecznie za pomocą przezudowej implantacji zastawki aortalnej pomimo bardzo krętego przebiegu tętnic udowej, biodrowej i aorty u pacjenta z przewlekłą obturacyjną chorobą płuc.

Słowa kluczowe: przezcewnikowe wszczepienie zastawki aortalnej, kręty przebieg naczynia, przezudowy, aorta, zwężenie

Corresponding author/Adres do korespondencji:

Dr. Ahmet Çağrı Aykan MD, Department of Cardiology, Ahi Evren Chest and Cardiovascular Surgery Education and Research Hospital, Soğuksu Mah, Çamlik Street, 61040 Trabzon, Turkey, tel.: 905058689461, fax: 904622310483, e-mail: ahmetaykan@yahoo.com

Praca wpłynęła: 27.05.2012, przyjęta do druku: 6.08.2012. 


\section{Introduction}

Transcatheter aortic valve implantation (TAVI) is an alternative therapy for surgery in patients with severe symptomatic aortic stenosis at high risk for surgery. Although TAVI is less invasive it is associated with major complications including valve embolization, stroke, perforation, coronary obstruction, and atrioventricular block [1-3]. Severe vascular tortuosity was associated with major vascular complication. The transapical approach is recommended in patients with vascular tortuosity [3].

Herein we present a case of aortic stenosis successfully treated with transfemoral aortic valve implantation despite severe femoral iliac and aortic tortuosity in a patient with severe chronic obstructive pulmonary disease.
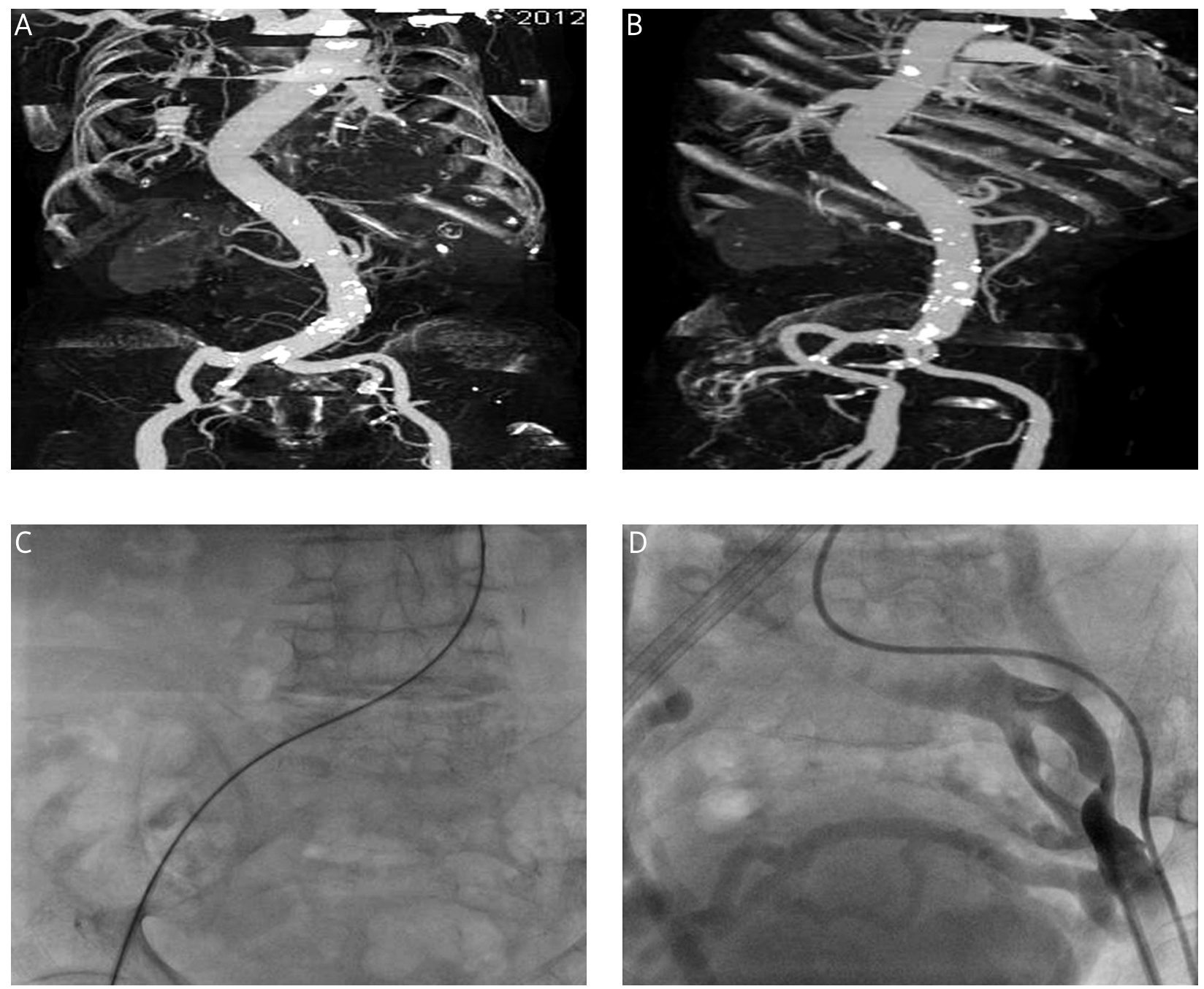

Fig. 1. A, B - Computed tomography demonstrated grade 3 tortuosity of femoral and iliac arteries and grade 2 tortuosity of aorta with mild calcification. $\mathrm{C}$ - The iliac tortuosity was straightened by a 0.035 Back-up Meier guidewire. D - Narrowed and tortuous iliac vein was demonstrated by venography

Ryc. 1. A, B-W tomografii komputerowej wykazano kręty przebieg tętnicy udowej i biodrowej (stopień 3) oraz aorty (stopień 2) z obecnością niewielkich zwapnien. C - zakręty w tętnicy biodrowej wyprostowano za pomoca prowadnika 0,0035 Back-up Meier. D - zwężona oraz kręta żyła biodrowa uwidoczniona za pomoca wenografii 
was planned for the patient. Transesophageal echocardiography showed an annulus diameter of $20 \mathrm{~mm}$; hence a $23 \mathrm{~mm}$ balloon expandable Edwards Sapien XT valve was selected. Computed tomography demonstrated grade 3 tortuosity of femoral and iliac arteries and grade 2 tortuosity of aorta with mild calcification (Figures $1 \mathrm{~A}, \mathrm{~B}$ ). Despite severe tortuosity, easy catheter and guide wire manipulation without difficulty during coronary angiography and mild calcification of iliac arteries and aorta, the transfemoral approach was planned. A 6 F catheter was introduced into the right common femoral artery through surgical cutdown. A $6 \mathrm{~F}$ Judkins right coronary catheter was introduced to the ascending aorta through a 0.038 guidewire. The 0.038 guidewire was exchanged with a 0.035 Back-up Meier guidewire which straightened the
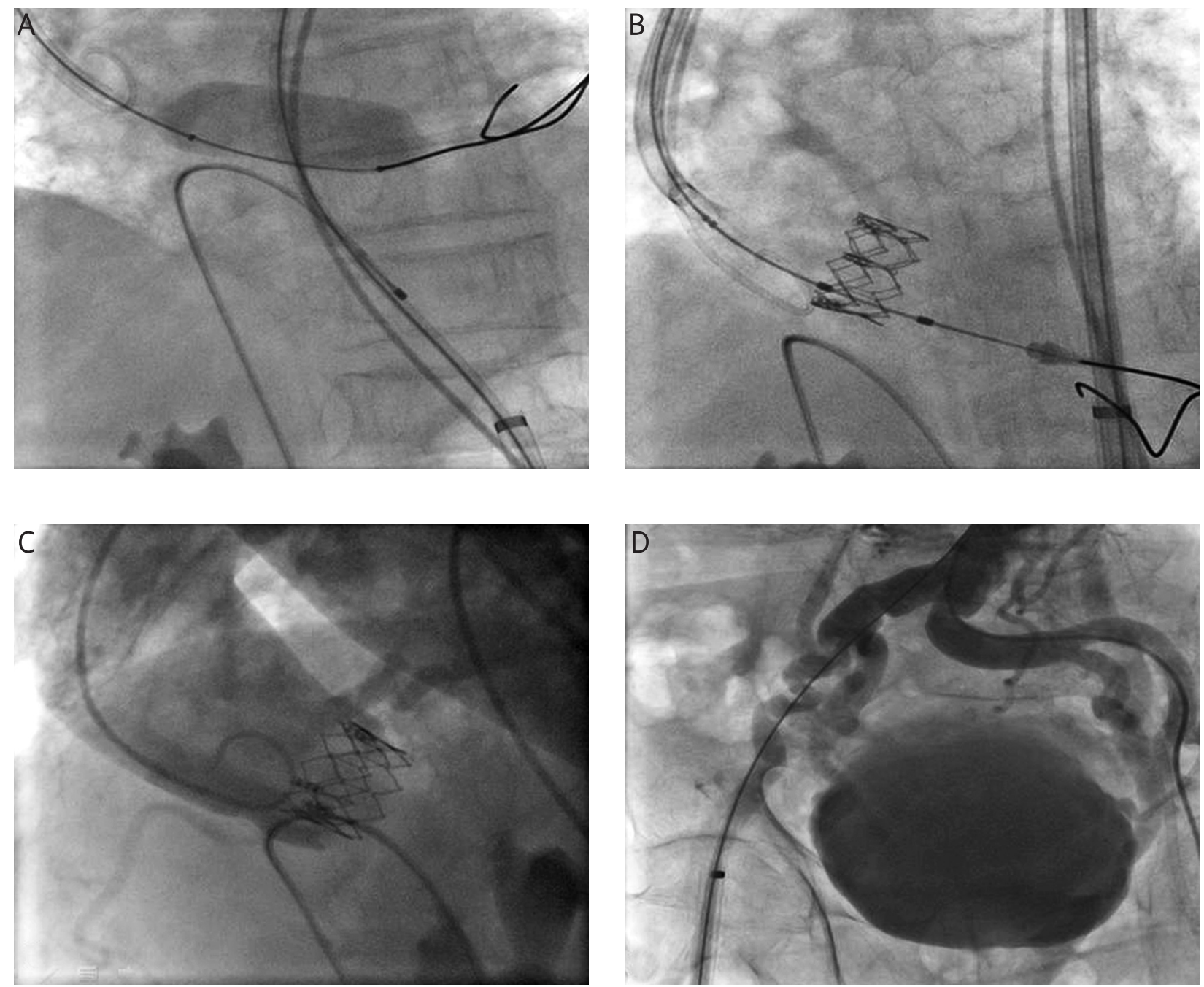

Fig. 2. A - The aortic balloon angioplasty is depicted. B, C - The successfully implanted $23 \mathrm{~mm}$ Edwards Sapien $\mathrm{XT}$ valve is shown. $\mathrm{D}$ - Tortuous right iliac and femoral artery demonstrated with angiography after removal of sheath

Ryc. 2. A - Plastyka balonowa zastawki aortalnej. B, C-Skutecznie implantowana zastawka aortalna Edwards Sapien XT $23 \mathrm{~mm}$. D - Kręte prawe tętnice biodrowa i udowa uwidocznione za pomocą angiografii po usunięciu cewnika 


\section{Discussion}

Vascular complications that significantly increase patient morbidity and mortality are common in transfemoral TAVI [3-5]. Thus severe iliofemoral tortuosities, severe calcification, porcelain aorta, significant atheroma of the femoral and iliac vessels constitute contraindications for transfemoral TAVI [3]. Vessel tortuosity was evaluated as according to the tortuosity score which was defined as: 0 no tortuosity; 1 mild tortuosity $\left(30^{\circ}\right.$ to $\left.60^{\circ}\right)$; 2 moderate tortuosity $\left(60^{\circ}\right.$ to $\left.90^{\circ}\right)$; and 3 marked tortuosity $\left(>90^{\circ}\right)$. Despite the marked tortuosity of the iliac and femoral arteries and moderate tortuosity of the descending aorta, we easily performed the coronary angiography. Furthermore the calcification grade is more important in the development of vascular complications, which was mild in this patient [2]. For advancing the valve a stiff wire is needed. The backup Meier, Lunderquist and Amplatz extra stiff wires are generally preferred. We used the backup Meier guidewire which totally straightened the tortuous iliac and femoral arteries and partially flattened the descending aorta. During advancement of the E-sheath we did not feel resistance. The guidewire should stay in the left ventricle during the procedure and advancing a valve catheter in a tortuous aorta may displace the guidewire; thus the guide wire should be detensioned by gently pulling back the catheter while advancing the valve over tortuous and angled areas. With increasing age the vascular tortuosity increases, and aortic stenosis is common among elderly patients. Thus patients with aortic stenosis may have varying degrees of vascular tortuosity. Calcium deposition is associated with rigidity of the vessels and an insult to the severely calcified vessel may cause perforation and rupture of the vessel. Furthermore, a heavily calcified vessel loses its elasticity.

In conclusion, vascular calcification may be more important than tortuosity and transfemoral TAVI may be performed in severely tortuous vessels successfully by an experienced interventional cardiologist.

\section{References}

1. Dağdelen S, Karabulut H, Alhan C. Acute left main coronary artery occlusion following TAVI and emergency solution. Anadolu Kardiyol Derg 2011; 11: 747-748.

2. Hayashida K, Lefèvre T, Chevalier B, et al. Transfemoral aortic valve implantation new criteria to predict vascular complications. JACC Cardiovasc Interv 2011; 4: 851-858.

3. Holmes DR Jr, Mack MJ, Kaul S, et al. 2012 ACCF/AATS/SCAI/STS Expert Consensus Document on Transcatheter Aortic Valve Replacement. J Am Coll Cardiol 2012; 59: 1200-1254.

4. Rodés-Cabau J, Webb JG, Cheung A, et al. Transcatheter aortic valve implantation for the treatment of severe symptomatic aortic stenosis in patients at very high or prohibitive surgical risk: acute and late outcomes of the multicenter Canadian experience. J Am Coll Cardiol 2010; 55: 1080-1090.

5. Webb JG, Chandavimol M, Thompson CR, et al. Percutaneous aortic valve implantation retrograde from the femoral artery. Circulation 2006; 113: 842-850. 